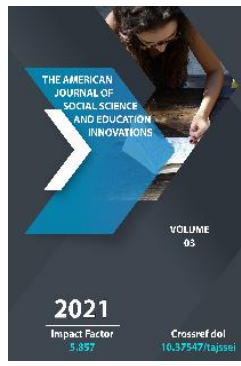

Journal Website: http://usajournalshub.c om/index,php/tajssei

Copyright: Original content from this work may be used under the terms of the creative commons attributes 4.0 licence.

\section{Views Of Abu Rayhan Beruni On Mysticism}

Lola Sadullaevna Yuldasheva

Lecturer, Candidate Of Fhilosophical Sciences, Department Of Social Sciences, Tashkent

Pharmaceutical Institute, Uzbekistan

Gulchekhra Baratovna Abdukarimova

Senior Lecturer, Tashkent State Transport University, Department Of Social Sciences, Uzbekistan

Lola Botirovna Sultonova

Senior Lecturer, Tashkent Pharmaceutical Institute, Department Of Social Sciences, Uzbekistan

\title{
ABSTRACT
}

This article discusses Orthodox fanaticism is a distortion of Islam, the development of arbitrariness in the face of adversity, love for humanity, praise for his knowledge and spiritual abilities, the formation of the view of him (man) as the highest discovery of nature, and so on.

\section{KEYWORDS}

Idea, adversity, humanity, discovery of nature, philosophical concept, religion, science pantheism, deism, fanaticism, humanism, natural power.

"It is impossible to understand the philosophical foundations of ideology without knowing history. Because the philosophical foundations of ideology were born in their time because of the historical reality."

(I.A. Karimov) 
Beruni also strongly supported the ideas of other great Central Asian thinkers, such as Khorezmi, Farobi, Ibn Sino, who represented the development of science and enlightenment, reason, justice and happiness in the difficult conditions of feudal oppression and superstition.

Orthodox fanaticism is a distortion of Islam, the development of arbitrariness in the face of adversity, love for humanity, praise for his knowledge and spiritual abilities, the formation of the view of him (man) as the highest discovery of nature, and so on. Academician $M$. $M$. Xayrullaev believes that this period is one of the important features of cultural life.

The philosophical concepts of Abu Nasr alFarabi and Ibn Sina later became the basis of the progressive philosophical teachings of Eastern Muslim thinkers such as Ibn Rushd, Nasriddin Tusi, Umar Khayyam, and Alisher Navoi.

\section{THE MAIN FINDINGS AND RESULTS}

Like many of his contemporaries, Abu Rayhan Beruni also left more than 150 works on these issues. In his correspondence with Ibn Sina, Jurjani, Bakhmanyar, and others, Beruni expressed his negative attitude towards orthodox Islamic beliefs, the destiny, and his opposition to pantheism, deism, fanaticism and humanism. Beruni's peculiar deism is manifested in his notions that he considers the being, the universe, nature, which decides all the processes of material reality, as some kind of "Natural Power". It remains only to give God "natural power", that is, the laws that operate in nature and are known from the very beginning.Beruni acknowledged the need to admit the eternal existence of material beginning, and even quotes from the Qur'an as proof of this: "His Throne was on the water (That is, nothing was created under the throne except water)". (Qur'an. XI-7).

From the literal meaning of this, it means the same thing, whether or not it refers to a particular object that Allah has commanded to be worshiped: it means that there is water and its seat besides Allah at that time.

Beruni admitted the existence of the spirit. But he laughed at those who thought it was possible to rain with the help of a magic spell. Whether it is raining here or not, Beruni wrote, is possible only by studying the location of the mountains, how the wind blows, and the movement of the clouds. He came to the conclusion that when it is not possible to find the right answer in science, they turn to religion. Although Beruni opposed the scientific worldview that arose from observation and experimentation with religious ideas, he was still in a dualistic position.

Beruni was well acquainted with the practices and rituals of the Sufis. This is evidenced by his book "Kitab patanjal al-hindi fi-l-khalas min al al-amsal", translated from the Arabic version of the "Yoga Sutra". The principles of yoga were known among the Sufis at that time. Later, the English orientalist $\mathrm{H}$. Rigger contributed to the publication of a book translated from Hindi by Beruni.

According to the information, Abu Rayhan Beruni was deeply acquainted with the ideas of Sufis about God, the universe, man, and analyzed the religious views of the Indian 
people in relation to Sufism, many behaviors, principles, and similarities in the yoga system in his book mentioned above.

One day, a young Abu Rayhan watched the astonishing behavior of a tourist dervish astrologer in the bazaar and listened to his thoughts on how wide and, at the same time, narrow the universe is. He narrated this to his teacher Abu Nasr Utbi. The Master first listened and then frowned and replied, "All this is the will of Allah, He is the Beneficent, the Creator. " In this way the young scholar became interested in the teachings of mysticism.

While visiting the bazaar in Ray, he met Sufi Abu Mahmud Hamid Ibn al-Khidr Khojandi, a famous astrologer of that time. From him he learnt the most perfect aspects of the science of astrology, as well as the theological knowledge of the structure of the universe.

It will be an honor to use the rich library of the Emir of Bukhara. During these years, he also met Abu Bakr Muhammad ibn Zakariya Razi, a great philosopher, physician and chemist. His views on Muslim theology were of great interest to the scholar. Many theories, including atomism, have been discussed in the debates and writings of scholars since the early ninth century, and of course this was well known to Beruni.

But in Razi's works, for the first time, he became acquainted with a holistic philosophical doctrine based on a fixed realistic understanding of the universe and a bold response not only to religious perceptions of the universe, but to religion in general.

Beruni, who has traveled to India several times, paid special attention to the religion and philosophy of the Indians. He studied classical sankya and yoga from the works of Patanjali, the founder of which lived in the 3rd century AD. Beruni brought one of Patanjali's works with him to the Treasury and, according to some sources, translated it into Arabic. His most famous work, "India", describes the religious and philosophical views of the Indians and regularly refers to the original sources.

It is evident that the scholar had mastered not only Arabic and Persian but also Greek, Hindi, and especially Sanskrit, the most difficult ancient language in the world, and was a polyglot scholar. For example, he was acquainted with Homer's "Iliad" and "Odyssey", as well as with Plato's "Laws" and "Felon". The encyclopedic scholar Beruni was well acquainted with the works of Aristotle, Archimedes, and Democritus, and highly valued the strengths of Greek philosophy.

In the works of Abu Rayhan Beruni there is a rich material about the "Avesto" - about the important principles of Zoroastrianism. According to Beruni, only two-fifths of the full text of the Avesto that has come down to us. In fact, this historical monuscript was thirty "naskh", about twelve naskh remained in the hands of the pagans.

Zoroastrianism is a relatively positive monotheistic doctrine that deifies the forces of nature that existed in primitive Central Asia.

It was a great example of courage for a great thinker like Beruni to use and propagate the works of pre-Islamic Arabic, Persian, and Sogdian writers at a time when Muslim scholars lived after Islam and only the slogans of Muhammad (peace be upon him) were accepted. . 
The number of poets mentioned in the scholar's works was more than one hundred and fifty, most of whom were Arab poets, but there were also many Greek, Roman, Central Asian, and Iranian writers. Well-known scientist Najmiddin Kamilov distinguishes and explains the logical connections between literature and science in the works of the scientist Beruni.

N.Kamilov highly appreciates Beruni's ability to distinguish and explain the logical connections between literature and science. According to Beruni, science and literature are explained by the assimilation of being by man, the properties of nature and society, the manifestations of the laws of which are formed in thinking. Through this he saw the closeness between science and art.

It takes literary evidence as scientific evidence and makes it the object of discussion and debate. At the same time, he repeatedly points out that there is a big difference between these two spheres, which are the perception of universe in the human mind. In this case, the scientist concludes that the main difference between literature, including poetry, and science is that poetry describes the human spirit, more precisely, the impact of universe on the human mind and the resulting situations.

It can be seen from the above ideas that Sufism has pantheistic ideas. Or the mystical teachings, ideas and aspirations of the IX-XI centuries have occupied the hearts and minds of all scholars and enlightened people. But even in Beruni's time, truly wise scholars, along with high-minded thinkers, first of all, there were those who served the existing ruling circles "wholeheartedly", chased after fame, presented various legends and myths, tasteless verses, or tried to appear as "famous literary critics".

Beruni strongly condemns them and describes them as "conscientious objectors." Abu Rayhan Beruni was very interested in the poetry of Abu Tammam and other Arab poets of the ninth century, who translated them from Arabic into Persian and wrote works and commentaries dedicated to them in Arabic. At the same time, he praised the philosophical views of the Hindus, taking and interpreting ideas about human ability from their philosophy.

\section{CONCLUSION}

Just as mystics glorified Islam, they explained man-made science and culture, art and literature as the invention of Allah, and poetry as a miracle of God. As a naturalist, Beruni had a unique approach to such views of the Sufis.

Beruni's greatness in particular lies in the fact that he followed religious-idealistic goals, but based on his own logic of the object of study, came to great assumptions and conclusions due to his consistent pursuit of truth, not afraid to describe them. It was with these efforts that Beruni contributed to the development of the direction of free thinking in mysticism.

\section{REFERENCES}

1. Karimov I.A. "I believe in the strong will of our wise people". "Fidokor newspaper". July $8,2000$.

2. Xayrullaev M.M. Cultural heritage and history of philosophical thought. T. «Uzbekistan», 1995, p. 110. 
The American Journal of Social Science and Education Innovations (ISSN - 2689-100x)

Published: April 30, 2021 | Pages: 759-763

Doi : https://doi.org/10.37547/tajssei/Volume03Issue04-122

2021: 5.857

3. The Holy Quran. The author of the translation and commentary is Alouddin Mansur. T .: «Cholpon», 1992, p. 147.

4. Klimovich A.I. Islam. M. G962, Pp. 270-271.

5. Trimingham J.S. Sufi Orders in Islam. Sofia, Moscow. 2002, p. 356.

6. Timofeev I. From the series ZhZL. Beruni. M $\therefore$ Young Guard, 1986, p. 231. 